\title{
The alternative macrophage relay: STAT6 passes the baton to EGR2
}

\author{
Jingwen Liao $^{1,2}$ and Diana C. Hargreaves ${ }^{1}$ \\ ${ }^{1}$ Molecular and Cellular Biology Laboratory, Salk Institute for Biological Studies, La Jolla, California 92037, USA; ${ }^{2}$ Division of \\ Biological Sciences, University of California at San Diego, La Jolla, California 92093, USA
}

\begin{abstract}
Alternative polarization of macrophages induced by IL-4 is important for homeostasis and tissue repair. Downstream from IL-4 receptor signaling, STAT6 activation is transient, but induces stable transcriptional changes. These data suggest that STAT6 induces second messengers to carry out the alternative transcriptional program. In this issue of Genes \& Development, Daniel and colleagues (pp. 1474-1492) identify EGR2 as a downstream regulator of STAT6 with broad functionality that further induces many transcription factors associated with alternative polarization. Identification of high EGR2 expression in a subset of mouse and human alveolar macrophages further highlights EGR2 as a conserved marker of alternatively activated macrophages.
\end{abstract}

Macrophages are innate immune cells that are highly heterogenous and plastic, able to adopt a spectrum of polarization phenotypes based on resident tissue environment and local immune signals (Amit et al. 2016). At the two ends of the macrophage polarization spectrum are classical polarization (M1) induced by Toll-like receptor and inflammatory ligands and alternative polarization (M2) induced by IL-4 or IL-13. In contrast to classically activated macrophages, which produce inflammatory and antimicrobial factors, alternatively polarized macrophages mediate tissue repair and regeneration (Van Dyken and Locksley 2013). The alternative polarization program is expressed in alveolar macrophages at steady-state as well as in pathologic conditions such as airway allergen clearance, helminth infection, and tissue repair following viral lung infections (Van Dyken and Locksley 2013).

IL-4 signals through the IL-4Ra, activating STAT6. STAT6 rapidly associates with chromatin at sites established during macrophage lineage determination by PU.1, AP-1, C/EBP, and IRF transcription factors (Horvath et al. 2019). STAT6 binds to both activated and repressed enhancers, which are characterized by gains or losses, respectively, in RNA polymerase II and PU.1 binding,

[Keywords: EGR2; IL-4; macrophage polarization; epigenomic regulation; transcription factor network]

Corresponding authors: dhargreaves@salk.edu

Article is online at http://www.genesdev.org/cgi/doi/10.1101/gad.345140. 120.
H3K27ac, eRNA transcription, and chromatin accessibility (Szanto et al. 2010; Czimmerer et al. 2018; Daniel et al. 2018a, 2018b). Although STAT6 association with chromatin is transient-STAT6 binding peaks at $1 \mathrm{~h}$ after IL-4 stimulation-STAT6-dependent transcriptional changes are observed as late as $24 \mathrm{~h}$ after IL-4 stimulation (Czimmerer et al. 2018; Daniel et al. 2018b). In addition, STAT6-dependent epigenetic changes at enhancers result in the potentiation of IL-4-responsive genes following a second IL-4 stimulation and the attenuation of LPS and IFN- $\gamma$ responses in macrophages previously treated with IL-4 (Piccolo et al. 2017; Czimmerer et al. 2018; Daniel et al. 2018a). These observations point to the presence of effectors downstream from STAT6 that facilitate and stabilize the alternative transcriptional program.

In order to identify transcription factors that connect early and late events of IL-4 stimulation, Daniel et al. (2020) categorized IL-4-responsive enhancers into early and late by mapping sites that gain p300 binding and $\mathrm{H} 3 \mathrm{~K} 27 \mathrm{ac}$ at $1 \mathrm{~h}$ and $24 \mathrm{~h}$, respectively. Using motif and ChIP-seq analysis, they confirmed transient binding of STAT6 to enhancers that are activated within $1 \mathrm{~h}$ of IL-4 stimulation. At enhancers that exhibit sustained or late activation, they uncovered a specific enrichment of EGR motifs. Moreover, they identified EGR2 as a downstream factor that binds selectively to sustained and late enhancers $24 \mathrm{~h}$ after IL-4 stimulation. EGR2 is a known regulator of alternative activation, and was shown previously to be up-regulated in IL-4/IL-13-activated macrophages (Jablonski et al. 2015; Veremeyko et al. 2018). The investigators demonstrate that Egr2 up-regulation following IL-4 stimulation is dependent on STAT6, and Egr2 expression is sustained via autoregulation. Mechanistically, they found that EGR2 is required for late enhancer activation following IL-4 stimulation and specifically to maintain BRD4, SWI/SNF complex, and RNA polymerase II binding at IL-4-activated enhancers, as well as H3K27ac levels and chromatin accessibility. Thus, following IL-4 stimulation, STAT6 activation of Egr2 transcription culminates in

(C) 2020 Liao and Hargreaves This article is distributed exclusively by Cold Spring Harbor Laboratory Press for the first six months after the full-issue publication date (see http://genesdev.cshlp.org/site/misc/ terms.xhtml). After six months, it is available under a Creative Commons License (Attribution-NonCommercial 4.0 International), as described at http://creativecommons.org/licenses/by-nc/4.0/. 
EGR2 binding at late enhancers associated with IL-4-responsive genes including Egr2 itself. These observations support a model in which EGR2 propagates STAT6 signal by initiating a self-sufficient program that sustains the expression of IL-4-responsive genes after STAT6 release from chromatin (Fig. 1).

Daniel et al. (2020) show that EGR2 exerts broad transcriptional control of IL-4 response genes and is required for $77 \%$ of IL-4-induced genes and $67 \%$ of IL-4-repressed genes. However, EGR2 does not act as a STAT6 coregulator, but rather localizes to a subset of late de novo enhancers devoid of STAT6 binding. Additionally, EGR2 is required for the IL-4-dependent repression and activation of 72 and 50 downstream transcription factors, respectively. The activity of these factors could explain the EGR2dependent changes at enhancers that lack EGR2 binding. Indeed, the investigators show that EGR2 induces Pparg, Klf4, Myc, and Bhlhe40, all of which have been shown previously to have roles in alternative activation (Fig. 1). The EGR2-dependent activation of downstream factors raises the potential cross-talk of EGR2 with new and previously described regulators of alternative activation; for example, PPAR $\gamma$ and RXR (Szanto et al. 2010; Daniel et al. 2018a, $2018 b$ ). In the context of IL-4 stimulation, up-regulation

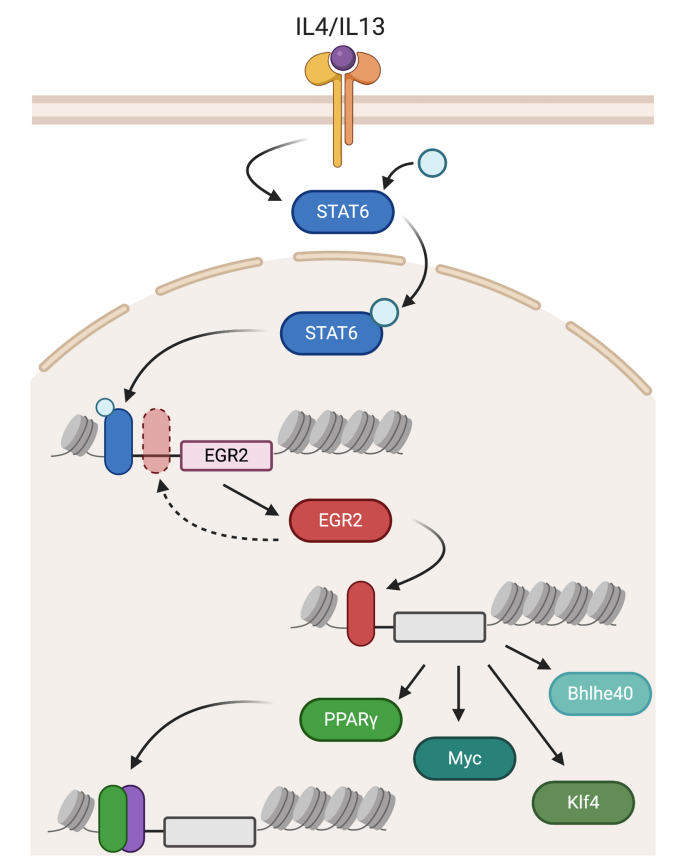

Figure 1. The STAT6-EGR2 activation cascade. Following stimulation of macrophages with IL-4 or IL-13, STAT6 becomes phosphorylated and translocates to the nucleus, where it binds to enhancers associated with the Egr2 locus and activates Egr2 expression. EGR2 in turn binds to de novo enhancers at target genes including Egr2 and activates downstream effectors including Pparg, Myc, Klf4, and Bhlhe 40 that induce the alterative polarization transcriptional program. Because STAT6 activation is transient, induction of EGR2 is necessary to carry out transcription associated with alternative polarization and transcriptional memory. Created with BioRender.com. of PPAR $\gamma$ results in PPAR $\gamma: \mathrm{RXR}$ heterodimeric binding to de novo enhancers that regulates a subset of IL-4-responsive genes and allows more robust binding of STAT6 following a repeat stimulation with IL-4 (Daniel et al. 2018a, 2018b). As an upstream regulator, EGR2 thus likely plays a role in the PPAR $\gamma$-dependent priming of the alternative activation program upon repeated exposure to IL-4 (Daniel et al. 2018a). Indeed, the EGR2 motif was found to be enriched at PPAR $\gamma$ :RXR binding sites that lack STAT6 binding, suggesting a coregulatory role for EGR2 in transcriptional memory (Daniel et al. 2018b). Similarly, EGR2 may play a role in the suppression of the inflammatory gene program in response to LPS or IFN- $\gamma$ in IL-4-treated macrophages (Piccolo et al. 2017; Czimmerer et al. 2018). These data demonstrate that IL4 sets off a multitiered transcriptional cascade involving STAT6, EGR2, and a host of downstream players with narrower specificity that underlies long-term epigenetic reorganization and alternative macrophage response.

The model put forth by Daniel et al. (2020) casts EGR2 as the linchpin or baton between the initial events of IL-4 activation and stable epigenetic memory (Fig. 1). In support of this model, the investigators demonstrate that Egr2 expression in humans is STAT6-dependent. Furthermore, Egr2 expression is high in a subset of macrophages in scRNA-seq data from mouse and human alveolar macrophages. The identification of EGR2 as a specific and conserved marker of alternatively polarized macrophages enables future efforts to identify alternatively polarized macrophages within various tissue-specific and disease-specific contexts from bulk and scRNA-seq data, paving the way for in vivo functional studies of transcription factors involved in alternative macrophage polarization.

\section{References}

Amit I, Winter DR, Jung S. 2016. The role of the local environment and epigenetics in shaping macrophage identity and their effect on tissue homeostasis. Nat Immunol 17: 18-25. doi:10.1038/ni.3325

Czimmerer Z, Daniel B, Horvath A, Rückerl D, Nagy G, Kiss M, Peloquin M, Budai MM, Cuaranta-Monroy I, Simandi Z, et al. 2018. The transcription factor STAT6 mediates direct repression of inflammatory enhancers and limits activation of alternatively polarized macrophages. Immunity 48: 75-90.e6. doi:10.1016/j.immuni.2017.12.010

Daniel B, Nagy G, Czimmerer Z, Horvath A, Hammers DW, Cuaranta-Monroy I, Poliska S, Tzerpos P, Kolostyak Z, Hays $\mathrm{TT}$, et al. 2018a. The nuclear receptor PPAR $\gamma$ controls progressive macrophage polarization as a ligand-insensitive epigenomic ratchet of transcriptional memory. Immunity 49: 615-626.e6. doi:10.1016/j.immuni.2018.09.005

Daniel B, Nagy G, Horvath A, Czimmerer Z, Cuaranta-Monroy I, Poliska S, Hays TT, Sauer S, Francois-Deleuze J, Nagy L. 2018b. The IL-4/STAT6/PPAR $\gamma$ signaling axis is driving the expansion of the RXR heterodimer cistrome, providing complex ligand responsiveness in macrophages. Nucleic Acids Res 46: 4425-4439. doi:10.1093/nar/gky157

Daniel B, Czimmerer Z, Halasz L, Boto P, Kolostyak Z, Poliska S, Berger WK, Tzerpos P, Nagy G, Horvath A, et al. 2020. The 
transcription factor EGR2 is the molecular linchpin connecting STAT6 activation to the late, stable epigenomic program of alternative macrophage polarization. Genes Dev (this issue). doi:10.1101/gad.343038.120

Horvath A, Daniel B, Szeles L, Cuaranta-Monroy I, Czimmerer Z, Ozgyin L, Steiner L, Kiss M, Simandi Z, Poliska S, et al. 2019. Labelled regulatory elements are pervasive features of the macrophage genome and are dynamically utilized by classical and alternative polarization signals. Nucleic Acids Res 47: 2778-2792. doi:10.1093/nar/gkz118

Jablonski KA, Amici SA, Webb LM, Ruiz-Rosado JdD, Popovich PG, Partida-Sanchez S, Guerau-de-Arellano M. 2015. Novel markers to delineate murine M1 and M2 macrophages. PLoS One 10: e0145342. doi:10.1371/journal.pone .0145342

Piccolo V, Curina A, Genua M, Ghisletti S, Simonatto M, Sabò A, Amati B, Ostuni R, Natoli G. 2017. Opposing macrophage po- larization programs show extensive epigenomic and transcriptional cross-talk. Nat Immunol 18: 530-540. doi:10.1038/ni .3710

Szanto A, Balint BL, Nagy ZS, Barta E, Dezso B, Pap A, Szeles L, Poliska S, Oros M, Evans RM, et al. 2010. STAT6 transcription factor is a facilitator of the nuclear receptor PPAR $\gamma$-regulated gene expression in macrophages and dendritic cells. Immunity 33: 699-712. doi:10.1016/j.immuni.2010.11.009

Van Dyken SJ, Locksley RM. 2013. Interleukin-4- and interleukin-13-mediated alternatively activated macrophages: roles in homeostasis and disease. Annu Rev Immunol 31: 317343. doi:10.1146/annurev-immunol-032712-095906

Veremeyko T, Yung AWY, Anthony DC, Strekalova T, Ponomarev ED. 2018. Early growth response gene-2 is essential for M1 and M2 macrophage activation and plasticity by modulation of the transcription factor CEBP $\beta$. Front Immunol 9: 2515. doi:10.3389/fimmu.2018.02515 


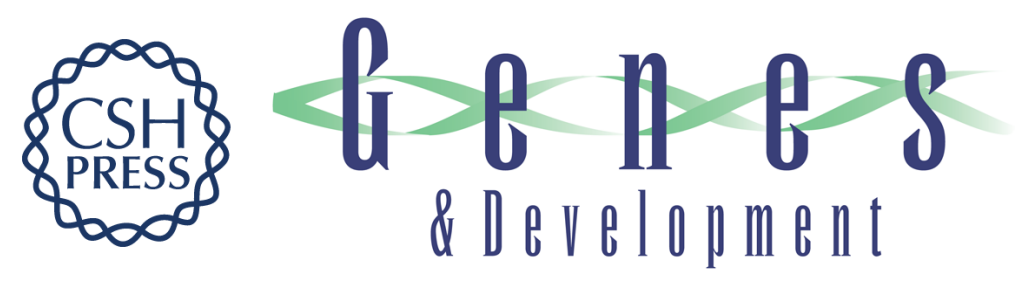

\title{
The alternative macrophage relay: STAT6 passes the baton to EGR2
}

\author{
Jingwen Liao and Diana C. Hargreaves
}

Genes Dev. 2020, 34:

Access the most recent version at doi:10.1101/gad.345140.120

\section{Related Content The transcription factor EGR2 is the molecular linchpin connecting STAT6 activation to the late, stable epigenomic program of alternative macrophage polarization \\ Bence Daniel, Zsolt Czimmerer, Laszlo Halasz, et al. \\ Genes Dev. November , 2020 34: 1474-1492}

References This article cites 11 articles, 1 of which can be accessed free at: http://genesdev.cshlp.org/content/34/21-22/1407.full.html\#ref-list-1

Articles cited in: http://genesdev.cshlp.org/content/34/21-22/1407.full.html\#related-urls

Creative This article is distributed exclusively by Cold Spring Harbor Laboratory Press for the first Commons six months after the full-issue publication date (see

License http://genesdev.cshlp.org/site/misc/terms.xhtml). After six months, it is available under a Creative Commons License (Attribution-NonCommercial 4.0 International), as described at http://creativecommons.org/licenses/by-nc/4.0/.

Email Alerting Receive free email alerts when new articles cite this article - sign up in the box at the top Service right corner of the article or click here.

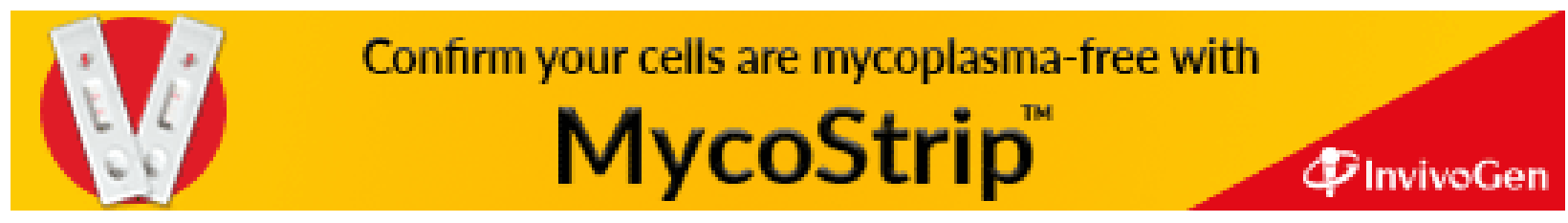

